\title{
Abdominal wall endometriosis: experience of the General Surgery Service of the Antônio Pedro University Hospital of the Universidade Federal Fluminense
}

\section{Endometriose de parede abdominal: experiência do Serviço de Cirurgia Geral do Hospital Universitário Antônio Pedro da Universidade Federal Fluminense}

Jorge Eduardo Faria Rocha Costa 1 [i]; Italo Accetta, ECBC-RJ²; Francisco José Santos Maia²; Renato Augusto Moreira de Sa ${ }^{3}$.

\begin{abstract}
A B S T R A C T
Objective: to study the characteristics of women undergoing abdominal surgery with suspected abdominal wall endometriosis or abdominal wall tumor, and to assess the association with age, race and previous cesarean delivery. Method: retrospective and analytical study carried out from January 2000 to December 2019, at the General Surgery Service of Hospital Universitário Antônio Pedro (HUAP) at Universidade Federal Fluminense (UFF). Medical records of 100 patients with abdominal wall endometriosis and other types of abdominal wall tumors were analyzed. Age, color, previous history of cesarean section or abdominal surgery and histopathological data were verified. The patients were classified as young adults (aged between 18 and 28 years and 11 months) and adults. The SPSS program was used for data analysis, Fisher's test with a significance level of 0.05 . Results: abdominal wall endometriosis with histopathological confirmation was found in $22 \%$, the mean age was $52.28 \pm 18.66$ which was lower when compared to other diagnoses. There was an association between previous cesarean section and abdominal wall endometriosis $(p<0.005)$. Conclusion: the women with a diagnosis of abdominal wall endometriosis had undergone previous cesareans (the majority) and were in an active reproductive age. Although the brown skin women were the most frequent, there was no statistical difference.
\end{abstract}

Keywords: Endometriosis. Abdominal Wall. General Surgery.

\section{INTRODUCTION}

A bdominal wall endometriosis is a rare disease ${ }^{1}$ characterized by the presence of endometrial tissue in any segment or depth of the abdominal wall, that is, outside the endometrium and myometrium. The extra pelvic location is less recurrent than the pelvic one, and has already been observed in the most varied organs and systems, such as lungs, bronchi, pleura, gallbladder, kidney, bladder, small intestine, large intestine, cecal appendix, oments, lymph nodes, and subarachnoid space $^{2-4}$.

Endometriosis usually affects women in the reproductive age group, with a maximum incidence in the third and fourth decades ${ }^{5}$. Its incidence is deemed higher in young women aged between 18 and 29 years old $^{6,7}$ Ectopic endometrial foci are usually under the influence of ovarian hormones, displaying all changes of the menstrual cycle, including bleeding. The malignant transformation of endometriosis is rare, but it cannot be ruled out ${ }^{8}$.

A study carried out in 2007 showed that early hysterotomy, associated with interrupted pregnancy using the procedure known as microcesarean section, is highly related to the development of endometriosis when compared with cesarean section performed at the end of pregnancy 9 . This factor is directly associated with the theory that the endometrium of early pregnancy is more

1 - Universidade Federal Fluminense, Faculdade de Medicina, Curso de Pós-Graduação, Mestrado Profissional em Saúde Materno Infantil - Niterói - RJ - Brasil 2 - Universidade Federal Fluminense, Faculdade de Medicina, Departamento de Cirurgia - Niterói - RJ - Brasil 3 - Universidade Federal Fluminense, Faculdade de Medicina, Departamento Materno Infantil - Niterói - RJ - Brasil 
favorable for the development of endometriosis than the endometrium of late pregnancy ${ }^{10}$.

When in the abdominal wall, endometriosis is preferably located close to a surgical scar. Although in most cases it occurs in patients with previous cesarean section ${ }^{11,12}$, it has also been observed in postoperative, conventional or laparoscopic, hysterectomy ${ }^{13,14}$, appendectomy and inguinal hernia incisions, and it has been described in patients without any previous intervention ${ }^{15}$. The classic symptomatology of abdominal wall endometriosis consists of a tumor that is very sensitive to palpation, intermittently painful, which increases in volume and sensitivity according to the phase of the menstrual cycle.

Regarding pathogenesis, no theory can fully explain the exact mechanism of formation of abdominal wall endometriosis, and it is likely to result from a combination of events. However, two theories suggest that the occurrence of abdominal wall endometriosis ${ }^{16}$, the most accepted being the hypothesis of contamination of the abdominal wall, particularly during uterine-opening procedures ${ }^{8,17}$. The other would be the occurrence of reflux, through the fallopian tubes, of particles from the endometrium to the abdominal cavity and blood and lymphatic vessels ${ }^{8,17}$. Another possibility would be the presence of primitive multipotential cells outside the uterus that under certain conditions would produce endometriosis, which would explain the presence of abdominal wall endometriosis in individuals who have not undergone previous surgery ${ }^{5,17,18}$.

As signs and symptoms, we can highlight the presence of a tumor in the abdominal wall that increases in volume and causes pain, especially in the menstrual period $^{8,19}$. In fact, the diagnostic suspicion must occur when the signs and symptoms clearly coincide with the phases of the menstrual period ${ }^{20,21}$. However, this relationship is not always clearly present, thus making it difficult to establish the cause of the problem. In this sense, it is important to establish a differential diagnosis with the following tumors: sarcomas, metastatic carcinomas, hernias, hematomas and granulomas, among others. It is noteworthy that the clear relationship between signs and symptoms and menstruation can favor the correct diagnostic impression of endometriosis ${ }^{8,22}$. It is also worth mentioning that there is usually an influence of ovarian hormones, which promote changes associated with the menstrual cycle, including bleeding ${ }^{8,22}$.

The treatment of abdominal wall endometriosis is essentially surgical and its main objective is the complete resection of the tumor, since no remaining endometrial tissue should remain in the affected area ${ }^{8,23}$. Therefore, the excision must be wide to remove all skin segments, subcutaneous tissue, muscles, aponeuroses and peritoneum potentially involved ${ }^{2,24-27}$. The literature recommends that the defect created by the extended excision be corrected with the abdominal muscles and aponeuroses, when possible. However, when this implies some tension in the suture lines, the most used option is a polypropylene prosthesis ${ }^{8,28}$. It is worth mentioning that in abdominal wall endometriosis, when there is an infiltration above $5 \mathrm{~mm}$ of the wall's depth involving the parietal peritoneum, there may be severe postoperative complications $^{29-31}$.

This is a well-known clinical entity in the gynecological literature, though it is still not well understood among general surgeons ${ }^{8}$. In this sense, as there is no safe clinical marker, the diagnosis occurs through histopathological analysis of a sample collected from an invasive procedure. Therefore, it is important to outline the characteristics of individuals with this disease in order to contribute to the diagnosis. It is believed that the incidence of abdominal wall endometriosis is higher in young women aged between 18 and 29 years ${ }^{6,7}$. Thus, the objective of this study is to report the experience of 22 cases of abdominal wall endometriosis, elucidating the importance of the surgical treatment used, in addition to highlighting the characteristics of women with this condition attended by the General Surgery Service of the Antônio Pedro University Hospital of the Universidade Federal Fluminense, and to observe the association with age, color and previous cesarean section.

\section{METHODS}

We conducted a descriptive, retrospective, quantitative study at the General Surgery Service of the Antônio Pedro University Hospital of the Universidade Federal Fluminense - HUAP/UFF, located at Rua Marquês de Paraná, 303, Centro, Niterói, RJ, Brazil. We collected data collection based on documentary research, through 
consultations with the medical records of the Medical Documentation Sector of HUAP. The variables used in this study were year of search in the sector, age, color, diagnosis of abdominal wall endometriosis, previous cesarean section, and histopathological result of the specimens, used only to confirm abdominal wall endometriosis. In addition, we classified patients according to age in young adults (aged between 18 and 28 years and 11 months) and adults (over 29 years) 6,7 .

We defined the sample size by convenience, therefore using no calculation for it. With the aid of the SISAIH 01 software, we searched ICDs of abdominal wall diseases. In addition, we performed a search in the Anatomopathology Sector of HUAP/UFF to obtain the desired records. We thus selected 100 patients, observing the cases of abdominal wall endometriosis and other types of abdominal wall tumors, to assess the incidence or absence of cases and their relationship with the variables studied. Therefore, the individuals did not undergo any personal intervention or interview. We collected data form medical records of patients who had a clinical picture of abdominal wall endometriosis and other types of tumors of the abdominal wall. The period of data collection was from January 2000 until December 2019.

Inclusion criteria were female patients, submitted to endometriosis surgery confirmed by histopathological examination or to resection of other abdominal wall tumors. The exclusion criteria were female patients diagnosed with incisional and non-incarcerated (reducible) hernias and intra-abdominal diseases giving a palpable mass effect.

The work was evaluated and approved by the Ethics in Research Committee of UFF on May 24, 2019 (Survey Protocol 12123219.1.0000.5243). Due to the study's retrospective nature, there was a waiver of the Informed Consent Form (ICF).

\section{DATA ANALYSIS}

We submitted the collected data to statistical analysis using the IBM SPSS software, version 20.0.

We assessed normality of the age variable with the Kolmogorov-Smirnov test and expressed it as mean \pm standard deviation when there was a normal distribution and as median and range otherwise. We presented the other results related to color, previous cesarean section, age group, and diagnosis as frequency and percentage. To compare cases according to age, we used the Student's t-test in case of normal distribution and the Mann-Whitney test otherwise. We applied the Fisher's exact test to analyze the association between the endometriosis diagnosis and color, age, and previous cesarean section of. The level of significance was $p<$ 0.05 .

\section{RESULTS}

Table 1 shows the characteristics of the studied patients. The average age of women was 33.23 years, the majority being adults (81.8\%). In addition, there was a higher prevalence of mixed races (54.5\%) and of previous cesarean sections (95.5\%).

Table 1. Characteristics of the patients included in the study.

\begin{tabular}{lc}
\hline Age, mean \pm standard deviation & Results \\
Young adult, n (\%) & $12(12 \%)$ \\
Adult, n (\%) & $88(88 \%)$ \\
Color* & \\
White & $29(33 \%)$ \\
Brown & $53(60 \%)$ \\
Black & $6(7 \%)$ \\
Previous cesarean section & \\
Yes & $45(\%)$ \\
Not & $55(55 \%)$ \\
Abdominal wall endometriosis & \\
Yes & $22(22 \%)$ \\
Not & $78(78 \%)$ \\
*12 medical charts did not record the color.
\end{tabular}

Of the evaluated cases, 22 had abdominal wall endometriosis. Table 2 shows the clinical data, diagnostic method, treatment, and postoperative evolution. The age ranged between 26 and 40 years (mean 33.23) and 21 patients had undergone previous cesarean section. Regarding the duration of signs and symptoms, the average was 2.66 years, ranging from 6 months to 7 years. 
Table 2 - Characteristics of patients diagnosed with abdominal wall endometriosis.

\begin{tabular}{|c|c|c|c|c|c|c|c|}
\hline Case & Age & $\begin{array}{c}\text { Previous } \\
\text { cesarean } \\
\text { section }\end{array}$ & $\begin{array}{l}\text { Symptom } \\
\text { time (years) }\end{array}$ & Location & $\begin{array}{l}\text { Image } \\
\text { exam }\end{array}$ & Treatment & $\begin{array}{c}\text { Postoperative } \\
\text { evolution }\end{array}$ \\
\hline 1 & 31 & Yes & 1.5 & RIF & US; TC & $\begin{array}{l}\text { Wide excision + } \\
\text { mash }\end{array}$ & Good \\
\hline 2 & 33 & Yes & 1 & LIF & US; TC & $\begin{array}{l}\text { Wide excision + } \\
\text { mash }\end{array}$ & Good \\
\hline 3 & 29 & Yes & 2 & RIF & US; TC & Wide excision & Good \\
\hline 4 & 40 & No & 1 & Umb. Scar & - & Wide excision & Good \\
\hline 5 & 35 & Yes & 3 & RIF & US; TC & Wide excision & Good \\
\hline 6 & 28 & Yes & 3 & LIF & US; TC & Wide excision & Good \\
\hline 7 & 35 & Yes & 1 & LIF & US & Wide excision & Good \\
\hline 8 & 40 & Yes & 1 & Umb. Scar & US & Wide excision & Good \\
\hline 9 & 26 & Yes & 7 & RIF & US & Wide excision & Good \\
\hline 10 & 28 & Yes & 7.5 & LIF & US & $\begin{array}{l}\text { Wide excision + } \\
\text { mash }\end{array}$ & Good \\
\hline 11 & 32 & Yes & 3 & LIF & US; TC & $\begin{array}{l}\text { Wide excision + } \\
\text { mash }\end{array}$ & Good \\
\hline 12 & 39 & Yes & 7 & LIF & US; TC & Wide excision & Good \\
\hline 13 & 40 & Yes & 0.5 & RIF & US; TC & Wide excision & Good \\
\hline 14 & 32 & Yes & 1 & LIF & US; TC & Wide excision & Good \\
\hline 15 & 32 & Yes & 2 & LIF & US & $\begin{array}{l}\text { Wide excision + } \\
\text { mash }\end{array}$ & Good \\
\hline 16 & 30 & Yes & 4 & RIF & US; TC & Wide excision & Good \\
\hline 17 & 34 & Yes & 1 & LIF & US; TC & Wide excision & Good \\
\hline 18 & 32 & Yes & 2 & Umb. Scar & - & Wide excision & Good \\
\hline 19 & 38 & Yes & 3 & LIF & US; TC & $\begin{array}{l}\text { Wide excision + } \\
\text { mash }\end{array}$ & Good \\
\hline 20 & 28 & Yes & 2 & LIF & US; TC & Wide excision & Good \\
\hline 21 & 30 & Yes & 2 & RIF & US; TC & Wide excision & Good \\
\hline 22 & 39 & Yes & 3 & RIF & US & Wide excision & Good \\
\hline
\end{tabular}

RIF: right iliac fossa; LIF: left iliac fossa; LF: left flank; Umb. Scar: umbilical scar; US: ultrasound; CT: computed tomography.

The main complaint in all cases was a tumor on the abdominal wall that increased in volume and became more painful with the beginning of the menstrual period. The tumor was located in the iliac fossa in 18 patients (eight on the right and 10 on the left), and in the left flank in one. All were located near the cesarean section surgical scar. In three cases, it was located in the umbilical region. All had, at palpation, imprecise limits, smooth 
consistency, and increased sensitivity.

Twenty women underwent ultrasonography, and 14, computed tomography. In three tomographic exams, the tumor captured contrast (only one patient was menstruating during the exam).

In all cases, there was extensive excision of the tumor and adjacent affected tissues (Figure 1). In six cases, a polypropylene mesh was necessary to the reconstruction of the abdominal wall, associated with drainage by active aspiration for 48 hours on two occasions.
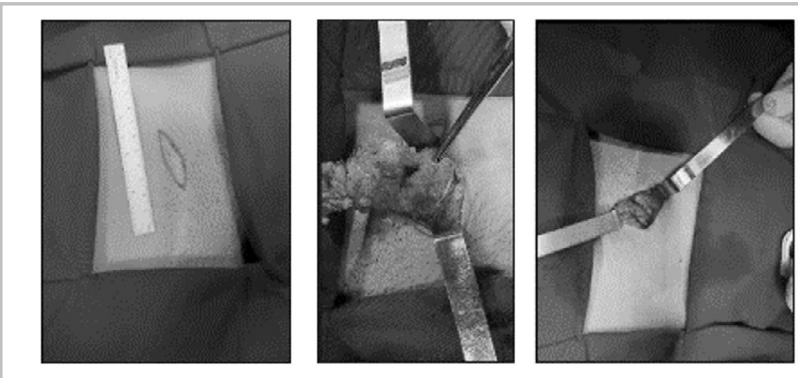

Figure 1. Stages of surgery with wide excision. Source: Authors.

After the follow-up until the outpatient discharge, the postoperative evolution of the patients was satisfactory and effective, with no recurrence or complication, in addition to improvement in pain, discomfort and tumor. In addition, the histopathological examination of the specimens confirmed the preoperative diagnostic impression of endometriosis in all cases.

Figure 2 shows the age distribution according to the diagnosis found. We found that women with abdominal wall endometriosis have a lower average age (33.23 \pm 4.46 years with endometriosis versus $57.65 \pm$ 17.59 years without it, $p=0.0001$ ).

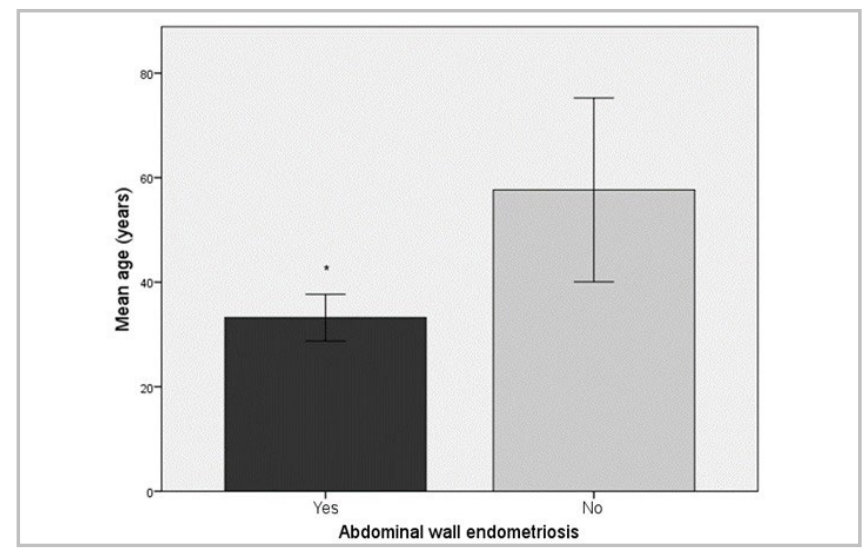

Figure 2. Age distribution according to diagnosis. ${ }^{*} p<0.05$, Student $t$-test.
However, analysis of endometriosis according to age showed no significant difference. In fact, women with endometriosis were younger, but we found the highest frequency in the age group considered adult, no in the young adult one (Table 3). Table 3 also shows the association between endometriosis and color. We observed no significant difference between them. Regarding previous cesarean section, we found an association with endometriosis, that is, the majority (95\%) of women with endometriosis underwent previous cesarean section (Table 3).

Table 3. Association between age group and abdominal wall endometriosis.

\section{Abdominal wall endometriosis}

$\begin{array}{lccc}\text { Variables } & \text { Yes } & \text { No } & \text { p-value } \\ \text { Young adults } & 5 & 7 & \\ \text { Adults } & 17 & 71 & 0.130 \\ & \text { Yes } & \text { No } & \\ \text { White } & 9 & 20 & \\ \text { Brown } & 12 & 41 & 0,143 \\ \text { Black } & 1 & 5 & \\ & \text { Yes } & \text { No } & \\ \text { Previous cesarean } & 21 & 24 & \\ \text { section } & 1 & 54 & 0,0001 \text { * } \\ \begin{array}{l}\text { No previous cesarean } \\ \text { section }\end{array} & & & \\ { }^{\star} p<0.05, \text { Fisher's exact test. } & & & \end{array}$

\section{DISCUSSION}

Endometriosis is a well-known disease in gynecological literature, but it is still not well understood among general surgeons ${ }^{8}$. In this study, we observed that patients with abdominal wall endometriosis had lower age compared with the ones with other diagnoses, and had undergone prior caesarean section. Thus, we could infer that abdominal wall endometriosis is related to previous cesarean section.

As we can see from the analysis of results, abdominal wall endometriosis generally affects women in the reproductive age group, with maximum 
incidence in the third and fourth decades ${ }^{5,32}$. The average age of individuals diagnosed with abdominal wall endometriosis was 33.23 years, similar to what was found by Khamechian, Alizargar, and Mazoochi $(2014)^{33}$, Khan et al. (2017) ${ }^{34}$, Yela et al. $(2017)^{35}$, Satyanarayana et al. (2018) $)^{36}$, Marras et al. $(2019)^{37}$, Ramos-Mayo \& Gil-Galindo (2019) ${ }^{38}$, and Zhang et al. $(2019)^{12}$. This age represents the stage in which the woman is reproductively active, initially described by Chun, Nelson and Maull (1990) ${ }^{24}$ and also found in more recent studies ${ }^{12,35,38}$. However, we found no association between abdominal wall endometriosis and the age group of young adults; in fact, there were more adult women (88\%).

When comparing the mean ages, Khan et al. $(2017)^{34}$ found no significant difference between groups, contrary to our findings, in which patients with abdominal wall endometriosis diagnosis were younger.

Although the majority of women are brown, we did not observe a significant difference in the association of color with abdominal wall endometriosis. There are no studies in the literature addressing this issue.

We observed an association between the diagnosis of abdominal wall endometriosis and prior cesarean section, present in $21 \%$ of the sample. In addition, among women with the condition, the percentage of prior cesarean section increased to $95 \%$, that is, of the 22 cases of endometriosis, 21 had undergone the procedure. This factor is well described in the literature, since endometrial tissue can be transported to the scar or adjacent tissues during surgery ${ }^{12,33-43}$. There was only one case in the present series with history of vaginal delivery, hence no previous operation.

Horton et al. (2008)40 carried out a review containing 455 cases of abdominal wall endometriosis and showed that $57 \%$ of the cases were associated with cesarean delivery, also elucidating relationships with hysterectomy (11\%) and other operations (13\%).

Khamechian, Alizargarl and Mazoochi (2014) ${ }^{33}$ studied 30 women diagnosed with abdominal wall endometriosis and showed that all had delivered by cesarean section.

Ecker et al. (2014) ${ }^{42}$ reported cases of abdominal wall endometriosis from experience of 12 years at an academic institute. They observed that of the 65 patients, $91.5 \%$ had undergone prior cesarean section and only six had never undergone any operation.

Oh et al. (2014) ${ }^{41}$ carried out a case study with nine patients and observed that six participants had undergone a previous cesarean section. This study also emphasized the importance of using an image exam to help in the diagnosis.

In 2017, a study conducted at the State University of Campinas (São Paulo State, Brazil), evaluated cases of abdominal wall endometriosis over a 10 -year period. They observed that $94 \%$ had undergone a previous cesarean section, $98 \%$ of whom felt pain and $36.5 \%$ had a tumor ${ }^{35}$

Celik et al. (2019) ${ }^{39}$ carried out a study with 53 patients, observing 49 cases of previous cesarean section, which represents approximately $92 \%$ of the cases. They also noted that this diagnosis has become common, due to the increase in cesarean rates.

Khan et al. (2017) 34 investigated the risk factors of women who underwent endometriosis abdominal wall resection and found that $88.2 \%$ had previous cesarean section. They also highlighted that $94.1 \%$ had undergone laparotomy.

Satyanarayana et al. (2018) ${ }^{36}$ studied 29 cases with endometriosis and found 16 cases associated with previous cesarean section, and in $56.25 \%$ the lesion was located close to the scar.

Marras et al. $(2019)^{37}$ carried out a retrospective, observational study lasting 11 years and included 37 women with abdominal wall endometriosis. They elucidated that, as for prior operations, $65.7 \%$ had undergone a caesarean section.

Zhang et al. (2019) ${ }^{12}$, in a study with 198 cases of endometriosis in the cesarean scar, found that all patients had undergone previous cesarean section. They also observed that $98.5 \%$ had abdominal mass and $86.9 \%$ reported pain.

Wasfie et al. (2002) ${ }^{11}$ reported that when endometriosis occurs in the abdominal region, it is preferably located close to or in a surgical scar. In accordance with these authors' findings corroborating ours, it is worth mentioning that one of the main risk factors for abdominal wall endometriosis is cesarean section. Grigore et al. (2017) ${ }^{44}$ confirmed the importance 
of reassessing the best surgical method and care during the procedure, these even being prophylactic methods. Wasfie et al. (2002)11 recommended vigorous wound postoperative irrigation with saline before closure of the abdominal wall. Koger et al. (1993)2 ${ }^{2}$, Patterson \& Winburn (1999) ${ }^{25}$ and Calabrese et al. (1997) ${ }^{45}$ also defend aspiration biopsy with a fine needle, which, according to the present study, would be contraindicated due to the possibility of spreading the disease in healthy tissues along the puncture path.

There are no reports in the literature on the association between abdominal wall endometriosis and multiple cesarean sections. However, Solak et al. $(2013)^{43}$ observed a strong association between the number of cesarean sections and size of the tumor, as they found large ones $(4.1 \mathrm{~cm}$ diameter) mainly in women previously subjected to 2 to 4 cesarean procedures, and the smaller ones $(1.9 \mathrm{~cm}$ in diameter) in women who had undergone 1 to 2 c-sections.

It is also worth mentioning the association with the body mass index. Khan et al. (2017)34 showed that the mean BMI was higher in women who were diagnosed with abdominal wall endometriosis (29.2 \pm $6.6 \mathrm{~kg} / \mathrm{m}^{2}$ in cases vs. $26.4 \pm 8.8 \mathrm{~kg} / \mathrm{m}^{2}$ in controls), justifying this finding by increased surgical difficulty occurring in obese patients, mainly related to suboptimal closure of the uterus after incision. Corroborating this finding, Marras et al. $(2019)^{37}$ observed, in 35 patients with endometriosis, $54.3 \%$ overweight (body mass index above $24.9 \mathrm{~kg} / \mathrm{m}^{2}$ ). In addition, Celik et al. $(2019)^{39}$ observed an average of $25.5 \pm 3.5 \mathrm{~kg} / \mathrm{m}^{2}$, that is, a value that is also considered to be overweight.

In order to provide more data for the collaboration of diagnosis and therapeutic conduct in the face of abdominal wall endometriosis, further studies would be necessary. A recent study by Azhar et al. (2019)46 shows what was initially diagnosed as inguinal hernia and, after histopathology, confirmed to be endometriosis. The authors thus stressed the importance of differential diagnosis of endometriosis in women of reproductive age with or without a history of endometriosis, especially in post-cesarean section patients.

In addition, the classic symptoms of abdominal wall endometriosis consist of a tumor with high sensitivity to palpation, intermittently painful, which increases in volume and sensitivity according to the phase of the menstrual cycle ${ }^{8}$. In the present series, patients' postoperative evolution was satisfactory, with no recurrence. Thus, these factors contributed to improve pain, discomfort and tumor.

Diagnostic suspicion must always be raised when the signs and symptoms clearly coincide with the phases of the menstrual period. However, this relationship is not always clear, which hinders the determination of the condition's etiology8. Thus, it is important to consider the differential diagnosis with the following tumors: sarcomas, metastatic carcinoma, hernias, bruises and granulomas, among others. In the present study, we observed a clear relationship between signs and symptoms and menstruation, which favored the correct diagnostic impression of endometriosis, later confirmed by histopathological examination.

The treatment of endometriosis of the abdominal wall is essentially surgical and its main objective is complete resection, since no endometrial tissue should remain in the affected area. Thus, the excision must be broad so that there is complete removal of all potentially involved skin segments, subcutaneous tissue, muscles, aponeuroses and peritoneum²,24,26,27,47. The defect created by the extended excision must be corrected with the abdominal muscles and aponeuroses. However, when there is tension in the suture lines, a polypropylene prosthesis is the most used ${ }^{8}$.

There is a need for more detailed studies regarding the analysis of the number of children and cesarean sections, to assess whether there is an influence on the size of the tumor. The association with previous laparotomy and hysterectomy, as well as with the nutritional status of these patients, also need better elucidation.

In short, abdominal wall endometriosis is a rare condition that causes, presenting a diagnosis based on histopathological analysis. Treatment is essentially surgical and its main objective is the complete resection of the lesion. We observed that all patients presented a satisfactory postoperative evolution and elucidated the relationship between previous cesarean section and abdominal wall endometriosis in women of reproductive age. 


\title{
R E S U M O
}

\begin{abstract}
Objetivo: estudar o perfil das mulheres submetidas a cirurgia abdominal com suspeita de endometriose de parede abdominal ou tumor de parede abdominal e analisar a associação com a faixa etária, cor e cesariana prévia. Métodos: estudo retrospectivo e analítico realizado no período de janeiro de 2000 a dezembro de 2019, no Serviço de Cirurgia Geral do Hospital Universitário Antônio Pedro (HUAP) da Universidade Federal Fluminense (UFF). Analisaram-se prontuários de 100 pacientes com endometriose de parede abdominal e com outros tipos de tumoração de parede abdominal. Idade, cor, histórico prévio de cesariana ou cirurgia abdominal e resultado histopatológico foram avaliados. As pacientes foram classificadas em adultas jovem (idade entre 18 e 28 anos e 11 meses) e adultas. Utilizou-se para a análise dos dados o programa SPSS e, teste de Fisher com nível de significância de 0,05. Resultados: endometriose de parede abdominal com confirmação histopatológica foi encontrada em $22 \%$ dos casos. A média de idade foi $52.28 \pm 18,66$, menor quando comparada a outros diagnósticos. Observou-se associação entre cesariana prévia e endometriose de parede abdominal $(p<0,005)$. Conclusão: as mulheres atendidas pelo Setor de Cirurgia da UFF com diagnóstico de endometriose de parede abdominal, na maioria, realizaram cesariana prévia e estavam em idade ativa, reprodutiva. Apesar da cor parda ter sido mais frequente, não se observou diferença estatística.
\end{abstract}

Palavras chave: Endometriose. Parede Abdominal. Cirurgia.

\section{REFERENCES}

1. Rindos NB, Mansuria S. Diagnosis and management of abdominal wall endometriosis: a systematic review and clinical recommendations. Obstet Gynecol Surv. 2017;72(2):116-22.

2. Koger KE, Shatney $\mathrm{CH}$, Hodge $\mathrm{K}, \mathrm{McClenathan} \mathrm{JH}$. Surgical scar endometrioma. Surg Gynecol Obstet. 1993;177(3):243-6.

3. Healy JT, Wilkinson NW, Sawyer M. Abdominal wall endometrioma in a laparoscopic trocar tract: a case report. Am Surg. 1995;61(11):962-3.

4. Gupta S, Shah S, Motashaw ND, Shah N, Darshana $\mathrm{V}$, Daye V. Case report: Bladder wall endometrioma. Ind J Radiol Imag. 2001; 11:23-4.

5. Wolf $Y$, Haddad R, Werbin N, Skornick Y, Kaplan $\mathrm{O}$. Endometriosis in abdominal scars: a diagnostic pitfall. Am Surg. 1996;62(12):1042-4.

6. Vieira JM. Transição para a vida adulta no Brasil: análise comparada entre 1970 e 2000. Rev Bras Estud Popul. 2008;25(1):27-48.

7. Barreto SM, Passos VMA, Giatti L. Comportamento saudável entre adultos jovens no Brasil. Rev Saúde Pública. 2009;43 suppl 2:9-17.

8. Accetta I, Accetta P, Accetta AF, Maia FJS, Oliveira APFA. Endometrioma de parede abdominal. Arq Bras Cir Dig. 2011;24(1):26-9.

9. de Oliveira MA, de Leon AC, Freire EC, de Oliveira $\mathrm{HC}$. Risk factors for abdominal scar endometriosis after obstetric hysterotomies: a case-control study. Acta Obstet Gynecol Scand. 2007;86910:73-80.

10. Scott RB, Te Linde RW. Clinical external endometriosis; probable viability of menstrually shed fragments of endometrium. Obstet Gynecol. 1954:4(5):502-10.

11. Wasfie T, Gomez E, Seon S, Zado B. Abdominal wall endometrioma after cesarian section: A preventable complication. Int Surg. 2002;87(3):175-7.

12. Zhang $P$, Sun $Y$, Zhang $C$, Yang $Y$, Zhang $L$, Wang $\mathrm{N}$, et al. Cesarean scar endometriosis: presentation of 198 cases and literature review. BMC Womens Health. 2019;19(1):14.

13. Nirula R, Greaney GC. Incisional endometriosis: an underappreciated diagnosis in general surgery. J Am Coll Surg. 2000;190(4):404-7.

14. Wilson $\mathrm{H}$, Shaxted E. Implatation endometrioma at a port site after laparoscopic abdominal supracervical hysterectomy. Gynaecol Endosc. 1999;8(4):245-7.

15. Thylan S. Abominal wall endometrioma in a laparoscopic trocar tract. A case report [comment]. Am Surg. 1996;62(7):617.

16. Steck WD, Helwig EB. Cutaneous endometriosis. JAMA. 1965;191:167-70.

17. Grigore M, Socolov D, Pavaleanu I, Scripcariu I, Grigore AM, Micu R. Abdominal wall endometriosis: an update in clinical, imagistic features, and management options. Med Ultrason. 2017;19(4):430-7

18. Ferhatoglu MF, Senol K. Primary abdominal wall endometriosis: presentation of rarely seen two cases. G Chir. 2018;39(2):107-10.

19. Tatli F, Gozeneli $O$, Uyanikoglu H, Uzunkoy A, Yalcin HC, Ozgonul A, et al. The clinical characteristics 
and surgical approach of scar endometriosis: A case series of 14 women. Bosn J Basic Med Sci. 2018;18(3):275-8.

20. Andres MP, Arcoverde FVL, Souza CCC, Fernandes LFC, Abrão MS, Kho RM. Extrapelvic endometriosis: a systematic review. J Minim Invasive Gynecol. 2020; 27(2):373-89.

21. Sumathy $S$, Mangalakanthi J, Purushothaman K, Sharma D, Remadevi C, Sreedhar S. Symptomatology and Surgical Perspective of Scar Endometriosis: A Case Series of 16 Women. J Obstet Gynaecol India. 2017;67(3):218-23.

22. Koninckx PR, Ussia A, Wattiez A, Zupi E, Gomel $\checkmark$. Risk factors, clinical presentation, and outcomes for abdominal wall endometriosis [comment]. J Minim Invasive Gynecol. 2018;25(2):342-3.

23. Huber M, Grosel J, Showen C. Recognizing abdominal wall endometriosis. JAAPA. 2019;32(7):30-3.

24. Chun JT, Nelson Jr HS, Maull KJ. Endometriosis of the abdominal wall. South Med J. 1990;83(12):14912.

25. Patterson GK, Winburn GB. Abdominal wall endometriomas: report of eight cases. Am Surg. 1999;65(1):36-9.

26. Çelik $M$, Bülbüloğlu, E, Büyükbeşe, MA, Çetinkaya A. Abdominal wall endometrioma: localizing in rectus abdominus sheath. Turk J Med Sci. 2004;34:341-3.

27. Kocakusak A, Arpinar E, Arikan S, Demirbag N, Tarlaci A, Kabaca C. Abdominal wall endometriosis: a diagnostic dilemma for surgeons. Med Princ Pract. 2005;14(6):434-7.

28. Pas K, Joanna SM, Renata R, Skręt A, Barnaś E. Prospective study concerning 71 cases of caesarean scar endometriosis (CSE). J Obstet Gynaecol. 2017;37(6):775-8.

29. Kasapoğlu I, Türk P, Dayan A, Uncu G. Does the presence of endometriosis cause a challenge for transvaginal oocyte retrieval? A comparison between patients with and without endometriosis. J Turk Ger Gynecol Assoc. 2018;19(3):151-7.

30. Lacour M, Ridereau Zins C, Casa C, Venara A, Cartier $V$, Yahya $S$, et al. CT findings of complications after abdominal wall repair with prosthetic mesh. Diagn
Interv Imaging. 2017;98(7-8):517-28

31. Poupon C, Owen C, Arfi A, Cohen J, Bendifallah $S$, Daraï E. Nomogram predicting the likelihood of complications after surgery for deep endometriosis without bowel involvement. Eur J Obstet Gynecol Reprod Biol X. 2019;3:100028.

32. Malutan AM, Simon I, Ciortea R, Mocan-Hognogi RF, Dudea M, Mihu D. Surgical scar endometriosis: a series of 14 patients and brief review of literature. Clujul Med. 2017;90(4):411-5.

33. Khamechian T, Alizargar J, Mazoochi T. 5-Year data analysis of patients following abdominal wall endometrioma surgery. BMC Womens Health. 2014; 14:151.

34. Khan Z, Zanfagnin V, El-Nashar SA, Famuyide AO, Daftary GS, Hopkins MR. Risk factors, clinical presentation, and outcomes for abdominal wall endometriosis. J Minim Invasive Gynecol. 2017;24(3):478-84

35. Yela DA, Trigo L, Benetti-Pinto CL. Evaluation of cases of abdominal wall endometriosis at Universidade Estadual de Campinas in a period of 10 Years. Rev Bras Ginecol Obstet. 2017;39(8):4037.

36. Satyanarayana MA, Sushma $V$, Kumar $K P$, Kumar VS, Murthy KR, Asha T. Endometriosis: A Clinicopathological Study of 29 Cases. J Clin Diagn Res. 2018;12(5):EC05-9.

37. Marras S, Pluchino N, Petignat $P$, Wenger JM, Ris $F$, Buches NC, et al. Abdominal wall endometriosis: An 11 -year retrospective observational cohort study. Eur J Obstet Gynecol Reprod Biol. 2019;4:100096.

38. Ramos-Mayo AE, Gil-Galindo G. Experience of the hernia and wall department in the management of abdominal wall endometriosis for 9 years. Cir Cir. 2019;87(4):385-9.

39. Celik HG, Karacan T, Kaya C, Uhri M, Savkli AO, Bahat PY, et al. Abdominal wall endometriosis: A monocentric continuous series and review of the literature. J Endometriosis Pelvic Pain Disord. 2019;11:1-7.

40. Horton JD, Dezee KJ, Ahnfeldt EP, Wagner M. Abdominal wall endometriosis: a surgeon's perspective and review of 445 cases. Am J Surg. 2008;196(2):207-12 . 
41. Oh EM, Lee WS, Kang JM, Choi ST, Kim KK, Lee WK. A Surgeon's perspective of abdominal wall endometriosis at a caesarean section incision: Nine cases in a single institution. Surg Res Pract. 2014;2014:765372.

42. Ecker AM, Donnellan NM, Shepherd JP, Lee TT. Abdominal wall experiences endometriosis: 12 years of experience at a large academic institution. Am J Obstet Gynecol. 2014;211(4):363.e1-5.

43. Solak A, Genç B, Yalaz S, Sahin N, Sezer TÖ, Solak I. Abdominal wall endometrioma: ultrsonographic features and correlation with clinical findings. Balkan Med J. 2013;30(2):155-60.

44. Grigore M, Socolov D, Pavaleanu I, Scripcariu I, Grigore M, Micu R. Abdominal wall endometriosis:

Received in: 27/03/2020

Accepted for publication: 14/04/2020

Conflict of interest: no.

Funding source: none. an update in clinical, imagistic features, and management options. Med Ultrason. 2017;19(4):430-7.

45. Calabrese L, Delmonte O, Mari R. [Endometriosis of the abdominal wall. Clinical case and review of literature]. Acta Biomed. 1997;68(1-2):35-43. Italian.

46. Azhar E, Mohammadi SM, Ahmed FM, Waheed A. Extrapelvic endometrioma presenting as acute incarcerated right inguinal hernia in a postpartum patient. BMJ Case Rep. 2019;12(9):e231213.

47. Singh KK, Lessels AM, Adam DJ, Jordan C, Miles WF, Macintyre IM, et al. Presentation of endometriosis to general surgeons: a 10-year experience. $\mathrm{Br} J$ Surg. 1995;82(10):1349-51.

\section{Mailing address:}

Jorge Eduardo Faria Rocha Costa

E-mail: jfarocosta@globo.com

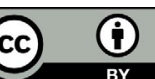

